\title{
Potential Areas for Growing Gmelina arborea Roxb., under Rainfed Conditions in Tabasco, Mexico
}

\author{
Genovevo Ramírez Jaramillo, Mónica Guadalupe Lozano-Contreras²* ${ }^{*}$, Jorge H. Ramírez Silva1 \\ ${ }^{1}$ Centro de Investigación Regional Sureste del Instituto Nacional de Investigaciones Forestales, Agrícolas y Pecuarias (INIFAP), \\ Mérida, México \\ ${ }^{2}$ Campo Experimental Mocochá del Centro de Investigación Regional Sureste del INIFAP, Mocochá, México \\ Email: *lozano.monica@inifap.gob.mx
}

How to cite this paper: Jaramillo, G.R. Lozano-Contreras, M.G. and Silva, J.H.R. (2019) Potential Areas for Growing Gmelina arborea Roxb., under Rainfed Conditions in Tabasco, Mexico. Agricultural Sciences, 10, 1206-1216.

https://doi.org/10.4236/as.2019.109090

Received: August 8, 2019

Accepted: September 23, 2019

Published: September 26, 2019

Copyright $\odot 2019$ by author(s) and Scientific Research Publishing Inc. This work is licensed under the Creative Commons Attribution International License (CC BY 4.0).

http://creativecommons.org/licenses/by/4.0/

\begin{abstract}
Gmelina arborea Roxb. (Melina), also known as white teak, is a tropical tree of great importance with multiple benefits. It is a timber species with renewal capacity and accelerated growth, highly durable and high quantity and quality pulp production, widely used in commercial programs of reforestation. In view of a possible increase of Melina areas in the state of Tabasco Mexico, information was needed in relation with the physical environment and natural factors in order to locate the most suitable areas under rainfed conditions. In this way, decision makers will be provided with a basic tool to direct and promote commercial plantations in the best suitable areas. The software Arc/View version 3.3 was used to process and analyze the information. The optimum agroclimatic requirements of Melina were identified and each variable factor was matched with those found at ground level. A cartographic mapping was carried out to regionalize and locate the optimal and suboptimal zones. It was determined that there are 191,532 ha of high potential and 542,573 ha of medium potential production areas of Melina in Tabasco, Mexico under rainfed conditions.
\end{abstract}

\section{Keywords}

Regionalization, Timber Species, Rapid Growth

\section{Introduction}

Gmelina arborea Roxb. (Melina), also known as white teak, is a tree of great importance for the tropics. The Gmelina belongs to the Plantae Kingdom, Angios- 
permae Division, Eudicotyledoneae Class, Asteridae Subclass, Lamiales Order and Lamiaceae Family. This species is native to India, Bangladesh, Sri Lanka, Myanmar, Thailand, southern China, Laos, Cambodia and Sumatra in Indonesia [1] [2]. Its importance lies in being: 1) a promising timber species due to the capacity for renewal and accelerated growth [3] [4] [5] [6] [7], 2) highly durable and produces a reasonable quantity and quality of pulp [8], 3) used in the manufacture of pulp and paper, furniture making, pairing and veneers for plywood [4] [5] [9] [10], 4) a forest species able to produce a rapid return on investment compared to other forest species [8] [11], 5) widely used in intercropping systems with pastures in commercial programs of reforestation in tropical countries for sawnwood mainly [12], 6) used as a fodder when its leaves are used as a food supplement for goats [13], 7) It favors the capture of carbon [14].

Because of its comparative advantages, $G$. arborea has been included in forest plantation programs in tropical countries such as Colombia [15], Costa Rica [16], Venezuela [17], Brazil [18], Honduras, Ivory Coast, Panama, the Philippines [19] and Nigeria [13].

In the particular case of Mexico, the first plantations of $G$. arborea were registered in 1971, as part of a project launched by the National Institute for Forestry Research (INIF) [20]. This project focused its attention on searching for potential species to establish commercial plantations in the country. Since then, this species has been established in different states for multiple purposes. By the year 2000, Melina plantations were grown in the states of Nayarit, Sinaloa, Tabasco and Veracruz, and for 2004, in Colima, Chiapas, Jalisco, Michoacan, Oaxaca, Puebla, San Luis Potosi, Tamaulipas and Yucatan [21].

Considered as a potential crop in the state of Tabasco, Mexico, many growers requested for information related to the potential areas suitable to produce $\mathrm{Me}$ lina with the lowest risks. So, it was in the light of this idea that this work aimed to characterize, under rainfed conditions, the physical environment and the natural factors to locate the most suitable areas for Gmelina to be grown as a commercial plantation.

\section{Materials and Methods}

The study was carried out at the laboratory of Geographic Information Systems (GIS) from INIFAP Southeast Regional Research Center, throughout the program for the development of the tropics located in the city of Merida, Yucatan, Mexico during the year 2013.

The delimitation of the production potential is based upon the search for agroecological requirements and their respective spatial query on existing maps, taking into account the climatic, topographic and soil variables, in addition to their intersections.

\subsection{Agro-Ecological Requirements Determination}

Crops distribution is currently marginalize by climate limits worldwide, either 
by default or by an excess of the vital needs for the individuals within different biotypes. Right from the moment the planting is performed, the plants are submitted to the climate components asynchronous variations, having those turned into the most determinant factors for the success of any given crop [22]-[27].

The particular needs and requirements of such crops are most commonly described in ranges, being usually reported by species or even genotype. The result of the diagnosis shall rely on the intervals taken into account; as a result, if optimal values are considered, the resultant potential areas may indeed provide a better yield and cultivation profitability.

The following criteria were considered to determine the potential areas for Gmelina to be cultivated under rainfed conditions: Those where all of the appropriate variables interacting with each other were considered as the most suitable for an optimal development; those where the correct climatic and soil characteristics interaction prevailed, despite some restrictions, were considered as suboptimal; finally, those considered as inadequate for the mechanical settlement of Gmelina cultivations were reported, too. Potential areas were determined taking into account only those opened for cultivation. Altitude, soil, temperature and annual rainfall levels were also taken into account in addition to climate, in order to have the optimal, suboptimal and inadequate Gmelina arborea cultivation areas defined (Table 1 ).

Table 1. Agroecological requirements for Gmelina arborea under rainfed conditions.

\begin{tabular}{|c|c|c|c|c|}
\hline Variable & Unit & Optimal & Suboptimal & Unfit \\
\hline Climate $^{*}$ & Types & Aw, Am, Af & $\mathrm{Cw}, \mathrm{Cf}$ & $\mathrm{Bs}, \mathrm{Bw}, \mathrm{Cs}$ \\
\hline $\begin{array}{c}\text { Average annual } \\
\text { temperature }\end{array}$ & ${ }^{\circ} \mathrm{C}$ & $22-34$ & $\begin{array}{l}16-22 \\
34-40\end{array}$ & $\begin{array}{l}<16 \\
>40\end{array}$ \\
\hline Elevation & msnm & $0-1000$ & $1000-1800$ & $>1800$ \\
\hline $\begin{array}{c}\text { Average annual } \\
\text { precipitation }\end{array}$ & $m m$ & $1200-3000$ & $\begin{array}{c}800-1200 \\
3000-4000\end{array}$ & $\begin{array}{l}<800 \\
>4000\end{array}$ \\
\hline Soil & Types & $\begin{array}{l}\text {-Andosols } \\
\text {-Fluvisols } \\
\text {-Luvisols } \\
\text {-Nitisols } \\
\text {-Acrisols }\end{array}$ & $\begin{array}{l}\text {-Cambisols } \\
\text {-Non-flooding Gleysols } \\
\text {-Non-flooding Vertisols }\end{array}$ & $\begin{array}{l}\text {-Solonchaks } \\
\text {-Flooding Gleysols } \\
\text {-Flooding Vertisols } \\
\text {-Phaeozems } \\
\text {-Arenosols } \\
\text {-Leptosols } \\
\text {-Regosols } \\
\text {-Rendzinas }\end{array}$ \\
\hline Soil texture & Types & Medium & Medium and Heavy & Light and Heavy \\
\hline Soil depth & $m$ & $>1$ & $1-0.5$ & $>50$ \\
\hline Soil $p H$ & Indicator & $5.0-6.0$ & $\begin{array}{l}4.0-5.0 \\
6.0-7.5\end{array}$ & $\begin{array}{l}<4.0 \\
>7.5\end{array}$ \\
\hline Drainage & Types & Good & Good & Deficient \\
\hline
\end{tabular}

*Types of climates: Af = Equatorial climate; Am = Monsoon climate; $\mathrm{Aw}=$ Tropical savanna climate; $\mathrm{Cw}$ = Humid subtropical climate; $\mathrm{Cf}=$ Warm oceanic climate; $\mathrm{Bw}=$ Warm desert climate; $\mathrm{Bs}=$ Warm semi-arid climate; Cs = Warm Mediterranean climate. Source: Own elaboration based on consultation of experts and different sources of information. 


\subsection{Identification or Regionalization of Potential Gmelina arborea Cultivation Areas}

The Arc/View version 3.3., software-developed by the American company ESRI-, was the program used for data process and analysis. Geo-referenced data can be represented with it, as well as the analysis of characteristics and distribution patterns for such data, looking forward to have it reported, afterwards [28]. All of the Arc/View activity took place within the project parameters, which were a collection of related documents controlled during the Arc/View session.

Projects may contain as many as five different views, tables, charts, layouts (or printouts) and scripts. The names of all of the documents contained in an Arc/View project were displayed through the Project window; then, a project had the status of all of these documents properly organized and stored; next, the project decided how and where such documents were meant displayed, keeping the document selection active and with the appearance of the application window defined, which is the same as making a quick picture of the Arc/View status at the moment of saving it. The project information was further stored in an ASCII format file, always with an *.Apr. Extension. Arc/View, which was mainly a maps vector generator.

The procedure was performed in Arc/View 3.3 (Figure 1) to take the variables intersection process into consideration in order to generate optimal, suboptimal and unsuitable potential areas. The maps were generated through cartographic intersections between polygons and potential classes were described and maintained in each process of intersection in vector processing; as a result, the final map provided information on all of the variables that were intercepted. These maps were more representative raster models as they were more accurate to

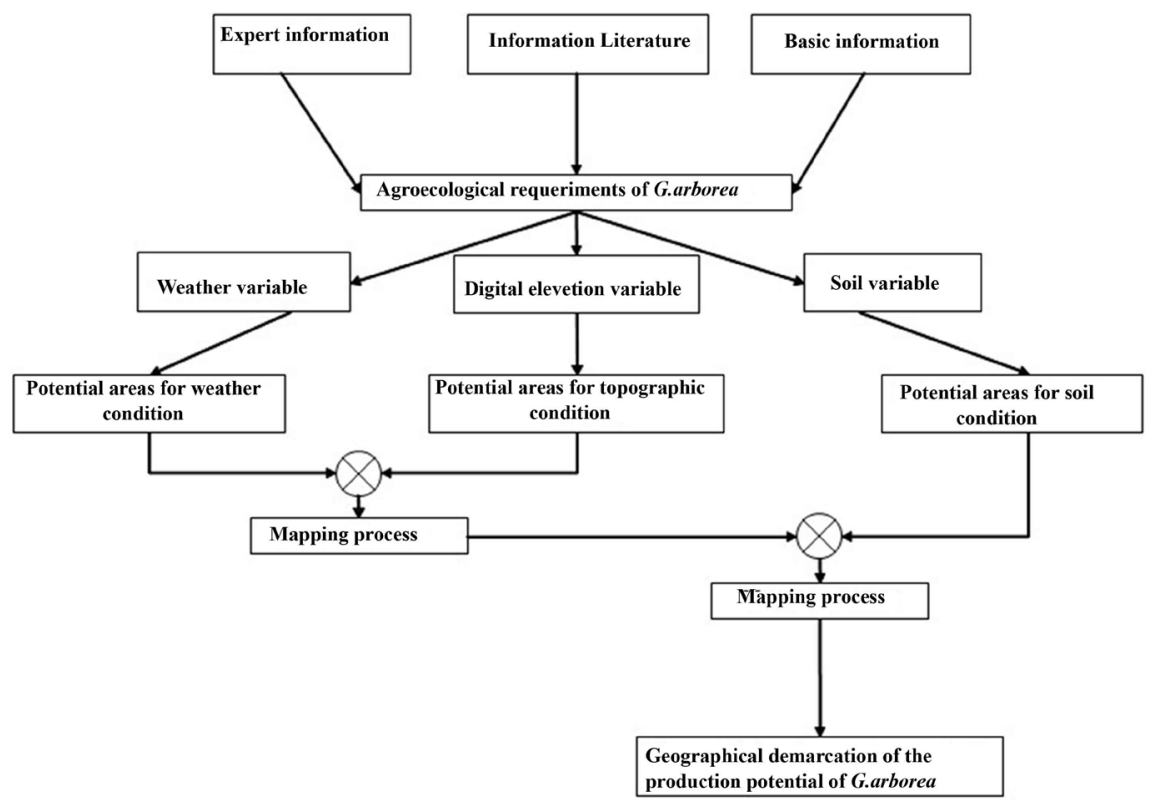

Figure 1. Methodological model used to determine the production potential. 
generate estimates of a given area, due to the fact that the maps involved in the processes were polygonal. Crop requirements were identified, and those suitable for the cultivation with regards to each variable that were analyzed in the study hereby; then, the performance of the mapping features were selected intersections.

\section{Results and Discussion}

\subsection{Potential Areas for G. arborea of Rainfed in Tabasco, Mexico}

In 2013 there were reported 5251 hectares of commercial plantations of G. arboreain the state of Tabasco, being scattered by municipality as follows: Balancán 3288, Huimanguillo 1050, Tenosique 683 and other municipalities 230 hectares [29]. According to the results, it was determined that under rainfed conditions there are 191,532 ha of high potential for Melina and 542,573 ha of medium potential (Figure 2). The areas with optimal potential are mainly distributed in the municipalities of Balancán, Huimanguillo, Tacotalpa, Teapa, Jalapa, Macuspana, Centro, Nacajuca and Tenosique whilst for the medium-potential areas the outstanding municipalities are: Cárdenas, Comalcalco, Cunduacán, Jalpa de Méndez, Nacajuca, Centro, Balancán and Emiliano Zapata. The optimal and suboptimal areas under rainfed conditions are shown in Figure 3.

\subsection{Soil and Climate}

The best sites for $G$. arborea to be established are located in those lands with available water and nutrients [30] due to the fact that the species grows well in deep, humid, well drained, aerated and fertile soils [31] with a slightly acidic, neutral or alkaline $\mathrm{pH}$ without salts [32]. It also grows better in valleys and in slightly sloping soils [33] since it is not adapted to medium sloping regions where leaching of nutrients is a common process inducing little growth and chlorotic foliage. It has been mentioned that in the valleys Gmelina presents a

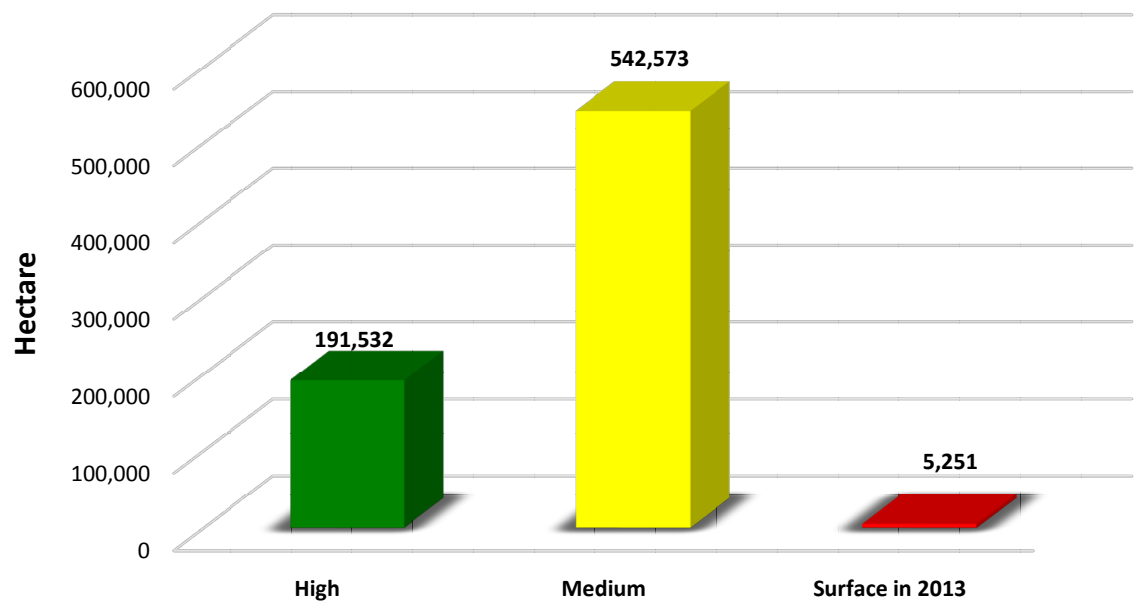

Figure 2. Potential areas for Gmelina arborea Roxb. under rainfed conditions in Tabasco, Mexico. 


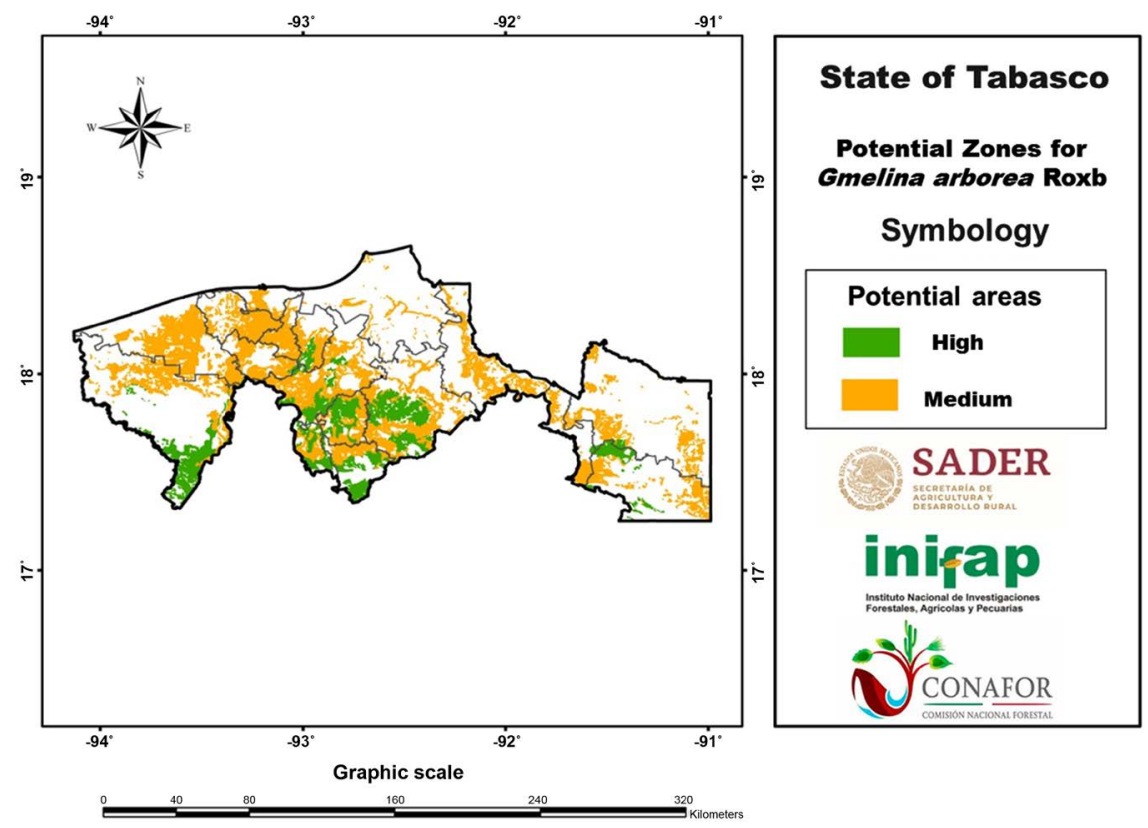

Figure 3. Geographical distribution of potential areas for Gmelina arborea Roxb. in Tabasco, Mex.

rapid growth and healthy leaves [34]. The most successful plantations in Latin America and Asia have been established in predominantly clayey soils with a depth of at least $60 \mathrm{~cm}$ [35] whilst there is a tend to fail in sandy soils.

The Soils. In Tabasco there are optimal soils for $G$. arborea classified as: Fluvisols, Luvisols, Andosols and Acrisols; as well as suboptimal soils such as Cambisols, Vertisols and Gleysols with slopes greater than 5\% (slopes less than 5\% are considered unsuitable due to the risk of flooding). The soils considered as unsuitable are the stony ones: Lithosols; the flooded ones, located in the lowlands: Solonchaks, Vertisols, Gleysols, Histosols, Phaeozem and the low water retention and poor fertility soils such as: Arenosols and Regosols (Figure 4).

The Climate. The tropical climates (A) are distinguished because their average annual temperature exceeds $18^{\circ} \mathrm{C}$ and their average rainfall fluctuates between $800 \mathrm{~mm}$ (in the Aw climate) up to $4000 \mathrm{~mm}$ (in the Af climate). The state of Tabasco has three types of climates: Warm humid with abundant rains in summer (Am), Warm humid with abundant rains through the whole year (Af) and Warm subhumid with rains in summer $\left(\mathrm{Aw}_{2}\right)$ [36] [37] [38]. The climate in Tabasco is suitable for forest plantations including G. arborea. The municipalities representing the high potential areas are: Huimanguillo, Tacotalpa, Teapa, Jalapa, Macuspana, Centro, Nacajuca and Tenosique with Af and Am climate types (Figure 5).

In general, the climate of Tabasco is hot humid with abundant rains in summer, with a rainfall of 1500 to $2750 \mathrm{~mm}$; the rainy season is from June to March. The average annual temperature is $27^{\circ} \mathrm{C}$, the maximum average temperature is $36^{\circ} \mathrm{C}$ and occurs in the month of May, the average minimum temperature is $18.5^{\circ} \mathrm{C}$ during the month of January; there are no frosts and as for hurricanes, its 


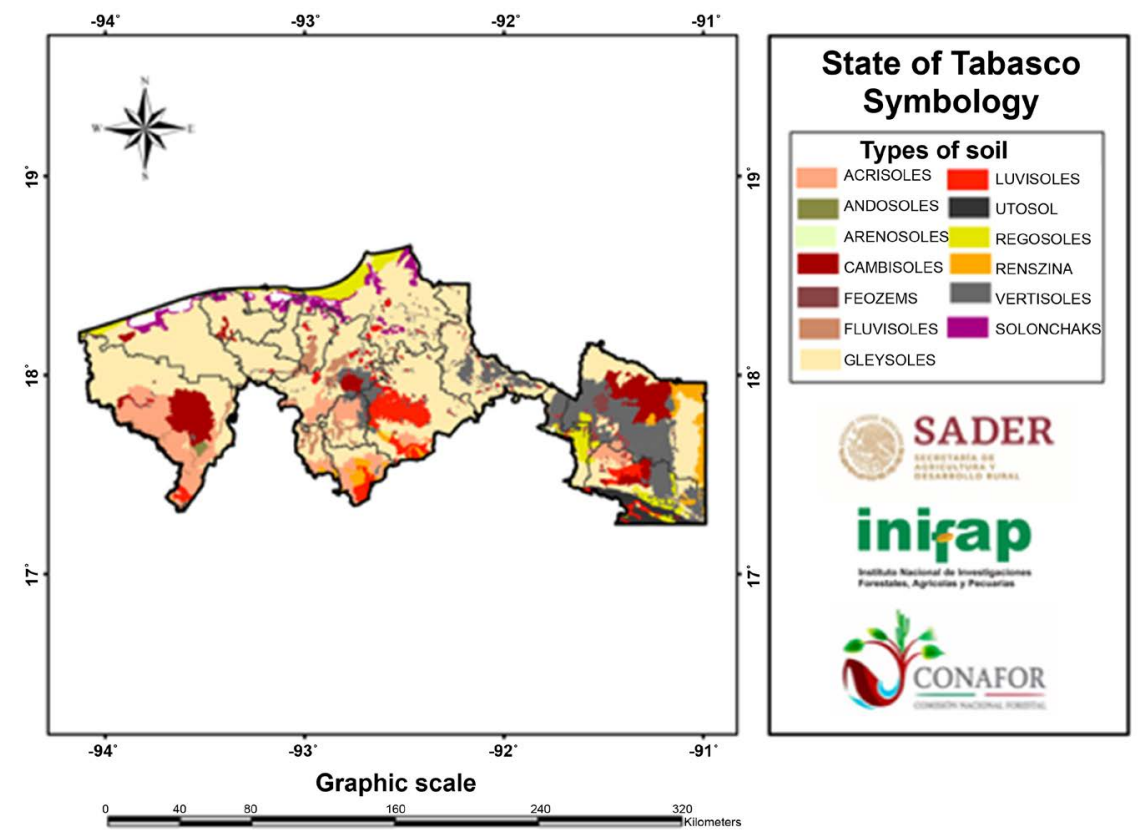

Figure 4. Soil types in Tabasco, Mexico.

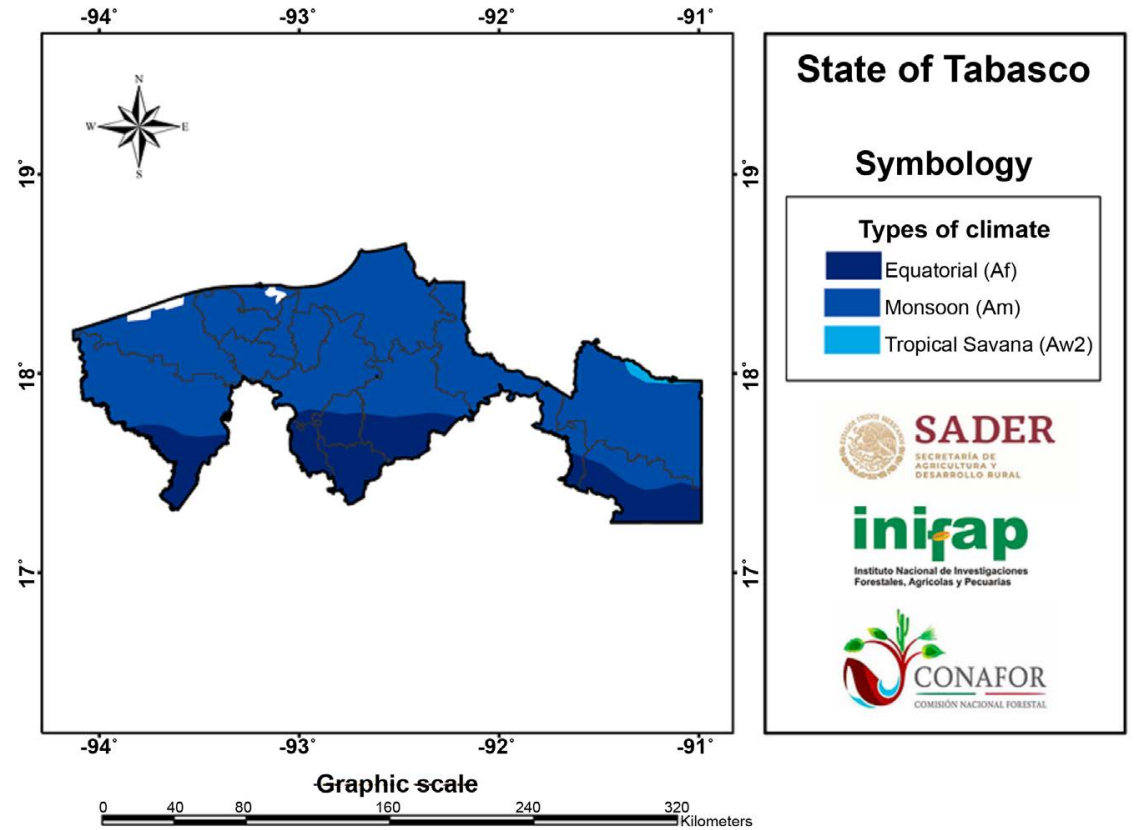

Figure 5. Climate conditions in Tabasco, Mexico.

coastline is of medium incidence. The optimum conditions for $G$. arborea are those where the annual temperature and precipitation are between $18^{\circ} \mathrm{C}-35^{\circ} \mathrm{C}$ and $1778-2286 \mathrm{~mm}$ respectively with a clear dry season and a relative humidity not lower than 40\% [31]. On the other hand, Stuhrmann et al. (1994) [34] found that, generally, G. arborea needs a dry season for better development, reaching the highest growth rates (more than $6.5 \mathrm{~cm}$ per month) in humid warm climates with abundant rains like those presented in Tabasco. 


\subsection{Physiographic Provinces}

The state of Tabasco is divided into two physiographic provinces: 1) toward the North the province of the coastal plain of the South Gulf 2) toward the South the Province of the Sierra de Chiapas and Guatemala. The latter one comprises more than $30 \%$ of the area formed by the municipalities of Tacotalpa, Teapa and Macuspana. These municipalities have been identified in this study as Melina cultivation areas with optimal potential (Figure 6). Also in this province are provided with mountains not higher than 1500 meters above sea level with steepy slopes and inter mountainous valleys that lead to the main rivers of the region. These heights are ideal for Gmelina arborea since it is a wide ecological range species adapted from 50 to 1300 masl [39] [40]; however, in commercial plantations it grows better from 90 to 1500 masl [41] where the annual temperature and precipitation is $18^{\circ} \mathrm{C}$ to $35^{\circ} \mathrm{C}$ and 1778 to $2286 \mathrm{~mm}$, respectively, and with a well-defined dry season [31].

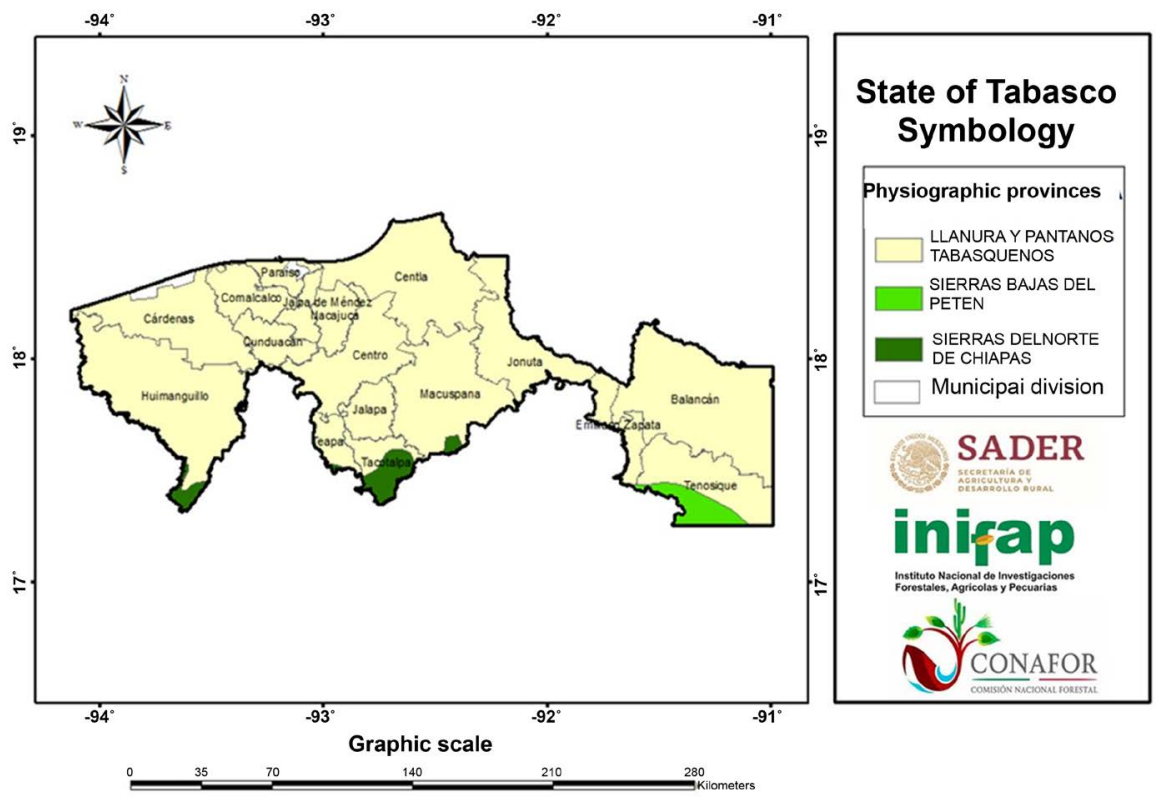

Figure 6. Physiographic provinces in Tabasco, Mexico.

Tabasco, in general, has a flat relief with a maximum elevation of 900 meters above sea level; the slopes vary up to a maximum of $5 \%$ and as a whole present adequate conditions for $G$. arborea growing.

\section{Conclusion}

The type of soil, precipitation and altitude are determining factors to define optimal and suboptimal potential areas for Melina. Tabasco has optimal agroclimatic conditions for commercial plantations. The high potential areas far exceed the current areas planted in the state. Huimanguillo, Tacotalpa, Teapa, Jalapa, Macuspana, Centro, Nacajuca and Tenosique are the municipalities with the best 
conditions for commercial plantations.

\section{Conflicts of Interest}

The authors declare no conflicts of interest regarding the publication of this paper.

\section{References}

[1] Rojas-Rodríguez, F., Arias-Aguilar, D., Moya-Roque, R., Meza-Montoya, A., Murillo-Gamboa, O. and Arguedas-Gamboa, M. (2004) Manual for Melina (Gmelina arborea) Producers in Costa Rica. 314 p.

[2] Ramos-García, J.R. (2016) Melina (Gmelina arborea Roxb.) Plants Production, with Two Pre-Germ Treatments in Small Plastic Bags at Nursery Level in Cantón Buena Fé, Rivers Province. Polytechnic High School of Chimborazo. Faculty of Natural Resources. Titling Thesis Presented as a Partial Requirement to Obtain the Title of Forest Engineer, Riobamba.

[3] Obregon, C. (2005) Gmelina arborea: Versatility, Renovation and Sustainable Productivity for the Future. In: Revista M\&M, Ed., The Furniture and Wood, Bogotá, Colombia, Special Edition 50, 14-20.

https://revista-mm.com/especies/gmelina-arborea-versatilidad-renovacion-y-produ ctividad-sostenible-para-el-futuro/

[4] Arnold, R.B. (1995) Investment in Fast-Growing Trees Offers Future Wood Procurement Advantages. Pulp \& Paper, 69, 135-137.

[5] Hornick, J.R., Zerbe, J.I. and Whitmore, J.L. (1984) Jari's Successes. A Massive Effort to Produce Pulp in the Amazon Has Yet to Make Money. But the Lessons Learned May Have Far-Reaching Consequence. Journal of Forestry, 62, 663-667.

[6] Ogbonnaya, C.I., Nwalozie, M.C. and Nwaigbo, L.C. (1992) Growth and Wood Properties of Gmelina arborea (Verbenaceae) Seedlings Grown under Five Soil Moisture Regimes. American Journal of Botany, 79, 128-132.

https://doi.org/10.1002/j.1537-2197.1992.tb13628.x

[7] Adebisi, M.A., Adekunle, M.F. and Odebiyi, O.A. (2011) Effect of Fruit Maturity and Pre-Sowing Water Treatment on Germinative Performance of Gmelina arborea Seeds. Journal of Tropical Forest Science, 23, 371-378. https://www.frim.gov.my/v1/jtfsonline/jtfs/v23n4/371-378.pdf

[8] Alison, K.S.W., Li, C., Dvorak, W.S. and Hong, Y. (2012) Genetic Diversity in Natural Populations of Gmelina arborea: Implications for Breeding and Conservation. New Forests, 43, 411-428. https://doi.org/10.1007/s11056-011-9288-2 https://link.springer.com/article/10.1007/s11056-011-9288-2

[9] Espinoza, J.A. (2003) Genetic Variation in Wood Density of Gmelina arborea Planted on Different Sites in Western Venezuela. Faculty of North Carolina State University, Department of Forestry Raleigh, Degree of Master of Science, Raleigh, $49 \mathrm{p}$.

[10] Wang, Z. (2004) Cultivation and Utilization of Gmelina arborea in South Yunnan, China. New Forests, 28, 201. https://doi.org/10.1023/B:NEFO.0000040947.94181.d8

[11] Ávila-Arias, C., Murillo, G.O., Arias-Aguilar, D., Flores, H.G.E., Murillo, R.C. and Hernández, C.W. (2015) Photosynthetic Behavior of Gmelina arborea Roxb. Genotypes at 15-Months-Old Plantation, South Pacific of Costa Rica. International Journal of Applied Science and Technology, 5, 79-93. 
http://www.ijastnet.com/journals/Vol_5_No_4_August_2015/9.pdf

[12] Tenorio, C., Moya, R. and Muñoz, F. (2011) Comparative Study on Physical and Mechanical Properties of Laminated Veneer Lumber and Plywood Panels Made of Wood from Fast-Growing Gmelina arborea Tres. Journal of Wood Science, 57, 134-139. https://doi.org/10.1007/s10086-010-1149-7

[13] Okagbare, G.O., Akpodiete, O.J., Esiekpe, O. and Onagbesan, O.M. (2004) Evaluation of Gmelina arborea Leaves Supplemented with Grasses (Panicum maximum and Pennisetum purpureum) as Feed for West African Dwarf Goats. Tropical Animal Health and Production, 36, 593-598. https://doi.org/10.1023/B:TROP.0000040937.42739.c6

[14] Marcene, E.A., Dalla, C.A.P., Sanquetta, C.R. and Schneider, C.R. (2006) Changes in Carbon Content and Individual Stock as Related to Growth of Gmelina arborea Roxb. in the Paraná Coastal Region, Brazil. Scientia Forestalis, 71, 55-63. https://www.ipef.br/publicacoes/scientia/nr71/cap06.pdf

[15] Espitia, M., Murillo, O. and Castillo, C. (2016) Expected Genetic Gain for Melina (Gmelina arborea Roxb.) in Córdoba (Colombia). Revista Arvore, 40, 71-80. https://doi.org/10.1590/0100-67622016000100008

[16] Morales, G. (2004) Potential of Gmelina arborea for Solid Wood Products. New Forests, 28, 331. https://doi.org/10.1023/B:NEFO.0000040966.76324.ea

[17] Calderón, M.D., Mora, A. and Aguilera, D.A. (2010) Variability of Gmelina arborea (Verbenaceae) Fiber Characteristics in Nine-Years Plantations (Portuguesa, Venezuela). Pittieria, 34, 73-87. http://190.168.5.19/index.php/pittieria/article/view/6632

[18] Moya, R.R., Filho, M.T. and Dias-Santos, T.C. (2007) Wood Anatomical Variation of Gmelina arborea Roxb. (Verbenaceae) Trees from Dry and Wet Tropical Climatic in Costa Rica. Forest Sciences, 35, 65-75. https://www.ipef.br/publicacoes/scientia/nr75/cap06.pdf

[19] Adebisi, M., Kehinde, T.F., Adekunle, M. and Adenaike, A. (2013) Seed Chemical Priming for Germination and Seedling Vigour Traits in Gmelina (Gmelina arborea) Sedes from Different Fruit Maturity Levels. Research Journal of Forestry, 7, 26-33. https://doi.org/10.3923/rjf.2013.26.33

[20] Patiño, V.F., Rodríguez, A., Marín, C.J. and Díaz, M.E. (1993) Gmelina arborea Roxb. Plant Production, Establishment and Plantations Management. Southeast Research Center, INIFAP, Yucatán, 167 p.

[21] CONAFOR (National Forest Commission of México) (2006) Compendium of Environmental Statistics 2006.

[22] Baradas, M.W. (1994) Crop Requirements of Tropical. In: Griffiths, J.F., Ed., Handbook of Agricultural Meteorology, Oxford University Press, New York, 10-15.

[23] Benacchio, S.S. (1982) Some Agroecological Requirements in 58 Crop Species with Production Potential in the American Tropic. FONAIAP-National Agricultural Research Center, Ministry of Agriculture and Breeding, Maracay, 35-39.

[24] Doorenbos, J. and Kassam, A.H. (1979) Effects of Water on Crop Yields. FAO Study: Irrigation and Drainage No. 33, Rome.

[25] Food and Agriculture Organization of the United Nations (FAO) (2014) Ecocrop, Ecological Requirements of Plant Species, Database. Rome.

[26] García, E. (1988) Modifications to the Köppen Climate Classification. UNAM, México, D.F.

[27] Ruiz, C.J.A., Medina, G., González, I.J., Ortiz, C., Flores, H.E., Martínez, A. and 
Byerly, K.F. (1999) Crop Agroecological Requirements. Technical Book No. 3. Regional Research Center, Pacific Center, INIFAP, SAGAR, Guadalajara.

[28] ESRI (1996) ArcView GIS. The Geographic Information System for Everyone.

[29] Government of the State of Tabasco (2015) Special Forestry Development Program 2013-2018. Ministry of Agricultural, Forestry and Fisheries Development, State Forestry Commission. https://tabasco.gob.mx/sites/default/files/09_Programa_especial_df.pdf

[30] Martínez-Zurimendi, P., Domínguez-Domínguez, M., Juárez-García, A., López-López, L., de-la-Cruz-Arias, V. and Álvarez-Martínez, J. (2015) Index Site and Timber Production in Gmelina arborea Forest Plantations in Tabasco, Mexico. Revista Fitotecnia Mexicana, 38, 415-425. http://37.redalyc.org/articulo.oa?id=61043041010

[31] Onyekwelu, C.J. (2004) Above-Ground Biomass Production and Biomass Equations for Even-Aged Gmelina arborea (ROXB) Plantations in South-Western Nigeria. Biomass and Bioenergy, 26, 39-46. https://doi.org/10.1016/S0961-9534(03)00100-4

[32] Muñoz, H.J., Sáenz, J.T., Orozco, G., Benavides, J.D. and Prieto, A.R. (2010) Evaluation of Commercial Forest Plantations in the Dry Tropic of the State of Michoacán. Technical Brochure No. 21. SAGARPA, INIFAP, CIRPAC, Uruapan Experimental Station, Michoacán, $54 \mathrm{p}$.

[33] Sukartiningsih, K.N. and Ide, Y. (1999) Clonal Propagation of Gmelina arborea Roxb. by in Vitro Culture. Journal of Forest Research, 4, 47-51. https://doi.org/10.1007/BF02760324

[34] Stuhrmann, M., Bergmann, C. and Zech, W. (1994) Mineral Nutrition, Soil Factors and Growth Rates of Gmelina arborea Plantations in the Humid Lowlands of Northern Costa Rica. Forest Ecology and Management, 70, 135-145. https://doi.org/10.1016/0378-1127(94)90081-7

[35] Urrego, J.B. (2004) Growth Potential of Gmelina arborea at 3 Years of Age in Colombia. New Forests, 28, 269-276. https://doi.org/10.1023/B:NEFO.0000040953.91091.69

[36] Köppen, W. (1918) Classification of Climates According to Temperature, Precipitation and Annual Run. Petermanns Mitteilungen, 64, 193-203.

[37] García, E. (1973) Modifications to the Köppen Climate Classification System (to Be Adapted to the Mexican Republic Conditions). National Autonomous University of Mexico, México, $246 \mathrm{p}$.

[38] Velázquez, V.G. (1994) Thehydraulic Resources of the State of Tabasco. Autonomous Juarez University of Tabasco State. Villahermosa, Tabasco, 242 p.

[39] Nair, P.K.R. (1993) An Introduction to Agroforestry. Kluwer Academic Publishers, Dordrecht.

http://old.worldagroforestry.org/Units/Library/Books/PDFs/32_An_introduction_t o_agroforestry.pdf? $\mathrm{n}=161$

[40] Lauridsen, E.B. and Kjaer, E.D. (2002) Provenance Research in Gmelina arborea Linn., Roxb. A Summary of Results from Three Decades of Research and a Discussion of How to Use Them. International Forestry Review, 4, 20-29. https://www.jstor.org/stable/43740942

[41] Osorio, L.F. (2004) Provenance Results of Gmelina arborea in Southwest Colombia at Three Years of Age. New Forests, 28, 179-185. https://doi.org/10.1023/B:NEFO.0000040944.23096.08 